\title{
ДО ПРОБЛЕМИ РОЗВИТКУ КОРОТКОЗОРОСТІ В СУЧАСНОЇ МОЛОДІ
}

\author{
Л. П. Кирилова ${ }^{1}$, О. І. Пилипишин ${ }^{2}$ \\ 'Обласна комунальна установа "Подільський медичний \\ фаховий коледж імені В. О. Жуковського» \\ ${ }^{2}$ Тернопільський національний медичний університет \\ імені І. Я. Горбачевського МОЗ Украӥни
}

У статті проаналізовано причини поширеності короткозорості серед молоді. Встановлено причини та фактори, що сприяють виникненню даного захворювання. Висвітлено причини появи даної патології, аналіз розвитку хвороби та методи її профілактики.

\section{TO THE PROBLEM OF DEVELOPMENT OF SHORT-SIGHTEDNESS IN YOUNG ADULTS}

\author{
L. P. Kyrylova ${ }^{1}$, O. I. Pylypyshyn ${ }^{2}$ \\ ${ }^{1}$ Regional communal institution "V. O. Zhukovsky Podillia Medical Professional College" \\ ${ }^{2}$ I. Horbachevsky Ternopil National Medical University
}

The article analyzes the reasons of the prevalence of myopia among young adults. The causes and factors that contribute to the development of this disease are identified. The causes of this pathology, analysis of the disease development and methods of its prevention are highlighted.

Вступ. У нашому житті зір має дуже велике значення - понад 90 \% інформації про навколишній світ ми отримуємо завдяки очам. Ще у 1818 р. Фрідріх Фріз стверджував: «Тільки зір дозволяє проникнути за межі Землі, до зірок, а на самій Землі він дарує найбільше вражень, охоплює найдовші відстані та забезпечує максимальну легкість розуміння. Людина, яка може бачити, сприймає все життя природи навколо себе через світло та кольори; око надає сенсу нашому життю» [1]. Завдяки зоровій сенсорній системі людина сприймає форму, величину, колір, рух предметів, а також їх розташування у просторі [2].

Патологія органа зору посідає перше місце в структурі захворювань, що виявляють у дітей підліткового віку [3]. При цьому займає найбільшу частку міопія слабкого ступеня зі спазмом акомодації [5]. У зв'язку з великою лабільністю органа зору в підлітковому віці зорова робота супроводжується напруженням усіх функцій очей і сама по собі може сприяти виникненню зорових розладів.
Основна частина. Серед численних факторів ризику порушення функцій зорового аналізатора, в тому числі розвитку міопії, виділяють: генетичні, порушення гігієни зору, ослаблення організму в результаті різних захворювань, нераціональне харчування, стреси, загальний фізичний розвиток підлітків тощо [6].

Зниження гостроти зору і порушення акомодації нині часто пов'язують зі збільшенням обсягу інформаційного навантаження і зростаючою комп'ютеризацією суспільства, використанням нових технологій у позаурочній та позашкільній роботі дітей та підлітків [8].

У зв'язку з погіршенням епідеміологічної ситуації в Україні, керуючись Постановою Головного державного санітарного лікаря України від 28.08.2020 р. № 50, на виконання листа МОН України «Про тимчасовий перехід на дистанційне навчання» від 12.10.2020 р., більшість закладів вищої освіти України перейшла на дистанційне навчання. 
Негативною стороною даного рішення $\epsilon$ збільшення навантаження на зоровий апарат, адже використовуючи даний тип навчання більшість матеріалу студенти опрацьовують саме в електронному вигляді, що призводить до зниження гостроти зору, а в подальшому - розвитку міопії. Під короткозорістю (міопією) розуміється аномалія заломлюючої сили, або рефракції.

Аметропія - аномалія рефракції ока, при якій головний фокус оптичної системи ока не збігається з сітківкою.

Короткозорість (міопія походить від грец. mуорs мружачи очі) - велика заломлююча сила оптичної системи ока, при якій задній головний фокус знаходиться перед сітківкою.

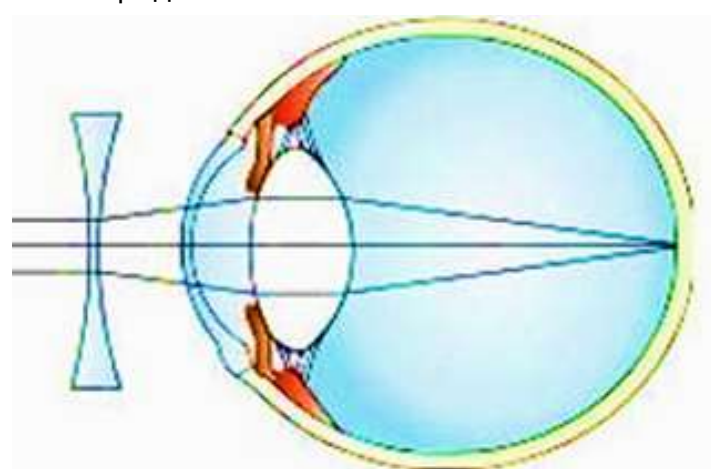

ЕМЕТРОПІЯ (норма)

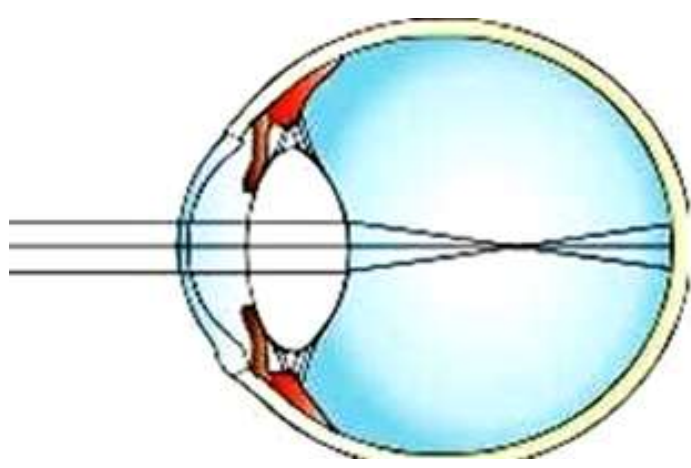

МІОПІЯ (короткозорість)

За статистикою від міопії, або короткозорості, страждає кожна третя людина на Землі. Ця патологія рефракції ока проявляється зниженням гостроти зору вдалину. Короткозорі люди погано бачать віддалені об'єкти, але добре бачать об'єкти, розташовані на близькій відстані.

Розвиток міопії. Міопія лише у вигляді рідкісного винятку спостерігається як уроджений стан рефракції. Більшість новонароджених має гіперметропічну рефракцію. Тільки з плином часу частина цих гіперметропічних очей переходить спершу в еметропічний, а потім і в міопічний. Перехід відбувається в період росту організму, тобто припадає головним чином на шкільні та студентські роки. у більшості випадків міопія, що досягла порівняно невеликого ступеня розвитку, так і залишається на такому рівні решту життя. Це відбувається переважно в перші роки шкільного життя, іноді пізніше, до 20-25 років. В останньому випадку відзначається зазвичай не постійне збільшення короткозорості до цього віку, а стрибкоподібне: ступінь ії збільшується на 6-7-му році життя, на 16-18-му і потім вже близько 2225 років [8].

Крім випадків, в яких міопія залишається стаціонарною, спостерігаються такі, в яких міопія збільшується протягом усього життя. Уже у віці 15 років вона достатньо розвинена, далі продовжує прогресувати та досягає досить високих ступенів (20-25-30 і більше діоптрій) [9]. Тому дуже важливо у цей віковий період (який припадає на I-II курс медичних коледжів) приділяти увагу діагностичним та профілактичним заходам, спрямованим на зниження випадків короткозорості серед студентів.

Клінічна класифікачія короткозорості

За ступенем:

- слабка - до 3,0 діоптрій включно;

- середня - до 6,0 діоптрій включно;

- висока - більше 6,0 діоптрій [10].

За рівністю або нерівністю величини рефракції обох очей:

- ізометропічна;

- анізометропічна [6].

За наявності або відсутності астигматизму:

- без астигматизму;

- $з$ астигматизмом [11].

За віковим періодом виникнення:

- уроджена;

- набута [11].

За походженням уроджену міопію поділяють на три форми:

1. Міопія внаслідок дискореляції між анатомічним і оптичним компонентом рефракції - поєднання відносно довгої осі ока з відносно сильною заломлюючою здатністю його оптичних середовищ. Ця форма зазвичай не прогресує після народження.

2. Міопія, пов'язана зі слабкістю склери і її підвищеною розтяжністю. Вона прогресує після народження і найбільш несприятлива прогностично.

3. Міопія при різних вадах розвитку очей - поєднується з косоокістю, ністагмом, колобомою оболонок ока, підвивихами кришталика, катарактою, 
частковою атрофією зорового нерва, дегенерацією сітківки [11].

За періодом виникнення:

- уроджена;

- набута в ранньому (дошкільному) віці;

- набута в шкільному віці;

- набута в дорослому віці.

За перебігом:

- стаціонарна;

- повільно прогресуюча;

- швидко прогресуюча [11].

За формою перебігу:

1) ускладнена:

- хоріоретинальна;

- вітреальна;

- геморагічна;

- змішана;

2) неускладнена.

За стадією морфологічних змін:

- початкова;

- розвинена за стадією функціональних змін ступінь зниження гостроти зору кращого ока 3 корекцією:

1) гострота зору $=0,8-0,5$;

2) гострота зору =0,4-0,2;

3) гострота зору =0,1-0,05;

4) гострота зору =0,04 і нижче [6].
Фактори, що впливають на розвиток міопії у студентів:

1) тривала робота за комп'ютером і читання 3 телефону;

2) зловживання комп'ютерними іграми;

3) гормональні зміни в підлітковому віці;

4) авітаміноз;

5) зниження імунітету;

6) порушення структури сполучної тканини, яка утворює склеру і підтримує форму очного яблука;

7) генетична спадковість;

8) порушення гігієни зору;

9) ослаблення організму в результаті різних захворювань;

10) нераціональне харчування;

11) стреси;

12) частота виникнення міопії також залежить від вiky.

Пік захворюваності спостерігали серед $(45,00 \pm$ 5,00) \% дітей віком 15-18 років.

На жаль, епідеміологічна ситуація в країні та в усьому світі сприяє розвитку короткозорості серед студентів через збільшення обсягу інформаційного навантаження, яке вони отримують при дистанційному навчанні (використання комп'ютерних технологій). Статистику короткозорості у дітей та підлітків в Україні на початок 2020 р. наведено на рисунку 1.

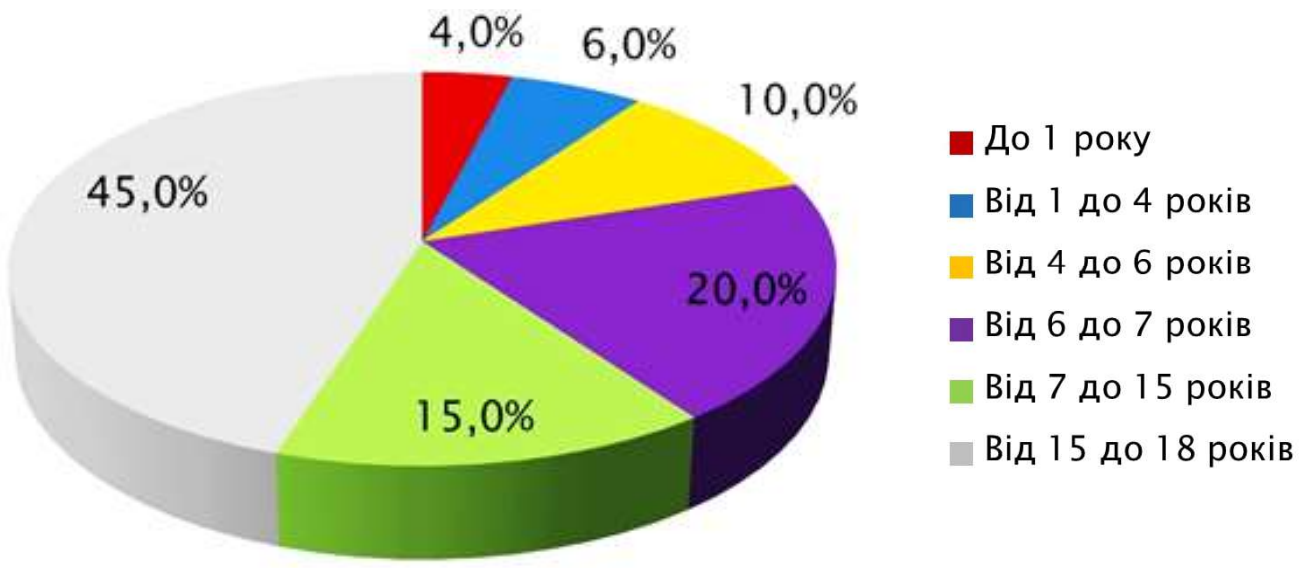

Рuc. 1. Статистика короткозорості у дітей та підлітків в Україні на початок 2020 р.

Висновки. Враховуючи загрозливу тенденцію щодо розвитку міопії серед молоді, необхідно проводити санітарно-просвітницьку роботу зі студентами медичного коледжу. Проблема в тому, що підлітки неналежним чином піклуються за власний зір: не дотримуються правил особистої гігієни ока, правильного харчування, зловживають ґаджетами. Хотілося 6, щоб студенти більш уважно ставилися до зору, дотримувались певних правил і заходів 3 профілактики очей, піклувались про своє майбутнє, тому що 80 \% інформації ми отримуємо завдяки зору. 


\section{СПИСОК ЛІТЕРАТУРИ}

1. Іонов І. А. Фізіологія сенсорних систем : методичні рекомендації / І. А. Іонов, Т. Є. Комісова. - 2-ге вид., доповн. та переробл. - Х., 2018. - 11 с.

2. Фізіологія / В. Г. Шевчук, В. М. Мороз, С. М. Бєлан та ін. - Вінниця : Нова Книга, 2012. - 448 с.

3. Баєва О. В. Особливості фізичного розвитку школярів з вадами зору / О. В. Баєва // Природничий альманах : збірник наукових праць, 2006. - С. 3-5.

4. Воротникова Е. К. Результаты лазерной субэпителиальной кератоэктомии (ЛАСЭК) / Е. К. Воротникова // Рефракционная хирургия и офтальмология. - 2006. № 2. - С. 6-9.

5. Бойчук Д. Є. Фактори ризику розвитку міопії у дітей на сучасному етапі / Д. Є. Бойчук // Актуальні питання теоретичної та клінічної медицини : збірник тез доповідей Міжнародної науково-практичної конференції студентів та молодих вчених, м. Суми, 10-12 квітня 2013 р. ; відп. за вип. М. В. Погорєлов. - Суми : СумДУ, 2013. - С. 191.

6. Апрелев А. Е. Анализ функциональных результатов лечения приобретенной миопии / А. Е. Апрелев, А. И. Кирилличев // Вестник офтальмологии. - 2009. № 2. - С. 43-45.
7. Азнабаев М. Т. Коррекция миопии высокой степени у детей методом рефракционной эпикератопластики / М. Т. Азнабаев, М. М. Бикбов, А. А. Бикбулатова // Офтальмохирургия. - 2004. - № 1. - С. 40-42.

8. Бойчук Д. Є. Сучасні аспекти короткозорості серед дітей міста Суми / Д. Є. Бойчук // Матеріали II Міжнародної науково-практичної конференції студентів та молодих вчених. - Суми, 2014. - С. 176-177.

9. Малиева Е. В. Возрастные показатели диаметра роговицы у пациентов с разными видами миопии и у лиц с эмметропией и гиперметропией / Е. В. Малиева, Н. Н. Бушуева // Офтальмологический журнал. - 2013. № 4. - С. 9-14.

10. Кузнецова М. В. Причины развития близорукости и ее лечение / М. В. Кузнецова. - М. : МЕДпресс-информ, 2004. - 168 c.

11. Попова Т. В. Особенности физического развития детей с нарушенным зрением / Т. В. Попова // Физическая культура. - 2008. - № 3. - С. 47-49.

Отримано 03.03.21 